\title{
GAMBARAN KEPERCAYAAN DIRI PENDERITA SKOLIOSIS DENGAN PENGGUNAAN SCOLIOSIS BRACE
}

\author{
Nur Rachmat ${ }^{1}$, Rizki Alfian Fauzi ${ }^{2}$ \\ ${ }^{1} J u r u s a n$ Ortotik Prostetik Poltekkes Kemenkes Surakarta \\ Email : dosenop@gmail.com
}

\begin{abstract}
The purpose is to return to the normal contour and align the spine and then makes the feeling of self-confidence sufferers re-arise. This research used quantitative research. The research method used in this study is research carried out with intrinsic case studies, the case taken are interesting cases to study. The research approach is purely qualitative by using direct contact methods, namely interviews. This study focused on the image of the patient's self-confidence using scoliosis. The results of the measurement with scoliosis can be seen from the degree asymmetry stem indicated on the cob angle. From the result of observation that the use of scoliosis brace can be seen, the patient has decreased self-confidence due to the pressure present on the scoliosis brace and the sound produced by the device.
\end{abstract}

\section{Keywords: Self-confidence, Scoliosis, Scoliosis Brace}

\begin{abstract}
ABSTRAK : Masa puber pada remaja perempuan akan banyak mengalami berbagai perubahan pada dirinya, baik fisik maupun psikologis. Perubahan-perubahan yang terjadi berakibat pada sikap dan perilaku remaja salah satu akibat hilangnya kepercayaan diri. Anak remaja yang awalnya sangat yakin pada diri sendiri, menjadi kurang percaya diri dan takut pada kegagalan karena perubahan fisik yang menonjol dan tidak dapat membebaskan diri dari tekanan yang dihadapainya. Tujuannya adalah mengembalikan pada kontur normal dan menyeleraskan tulang belakang kemudian membuat perasaan kepercayaan diri penderita kembali timbul. Penelitian ini menggunakan penelitian kuantitatif. Metode penelitian yang digunakan dalam penelitian ini adalah penelitian yang dilakukan dengan studi kasus yang bersifat instrinsik, yaitu kasus yang yang diambil merupakan kasus yang menarik untuk diteliti. Pendekatan penelitian adalah murni kualitatif dengan menggunakan metodemetode kontak langsung, yakni wawancara. Penelitian ini terfokus pada gambaran kepercaaa diri pasien dengan menggunakan skoliosis. Hasil dari pengukuran dengan skoliosis dapat diliat dari batang asimetri derajat yang tertera pada cob angle. Dari hasil observasi penggunaan skoliosis brace dapat diliat bawasannya pasien memiliki rasa percaya diri yang menurun dikarenakan tekanan yang ada pada alat skoliosis brace dan bunyi yang dihasilkan oleh alat tersebut.
\end{abstract}

Kata kunci : Kepercayan diri, Skoliosis, Skoliosis Brace 


\section{Pendahuluan}

Masa remaja dimulai sekitar usia 10 hingga 13 tahun dan berakhir pada sekitar usia 18 hingga 22 tahun. Individu yang tergolong remaja akhir cenderung berada dalam keadaan labil dan emosional karena mengalami banyak perubahanperubahan yang berlangsung cepat baik perubahan hormonal, fisik, psikologis, maupun sosial. Salah satu akibat perubahan ini adalah hilangnya kepercayaan diri. kepercayaan diri adalah sikap positif seorang individu yang memampukan dirinya untuk mengembangkan penilaian positif, baik terhadap diri sendiri maupun terhadap lingkungan/ situasi yang dihadapinya. Idealnya kepercayaan diri yang dimiliki individu haruslah berada pada kategori sangat tinggi. Hal ini dimaksud agar individu mampu mengembangkan aspek-aspek yang ada dalam dirinya, dibutuhkan kepercayaan diri yang tinggi pada individu tersebut (Deni \& Ifdil, 2016).

Masa remaja adalah masa peralihan masa kanak-kanak dan dewasa (Berk, 2012). Masa peralihan tersebut ditandai dengan adanya perkembangan fisik dan kognitif. Aspek psikologis dari perubahan fisik yang dialami remaja yaitu remaja sangat memperhatikan tubuh dan mengembangkan citra individual terkait gambaran tubuh remaja (Santrock, 2002). Oleh karena itu remaja pada umumnya berusaha mengembangkan fisik yang dimiliki menjadi lebih sempurna. Akan tetapi tidak semua remaja memiliki tubuh yang normal. Remaja yang memiliki gangguan atau disabilitas tentu akan melakukan usaha yang lebih besar dalam mengembangkan fisiknya dibanding dengan remaja yang tidak mengalami disabilitas. Salah satu disabilitas yang diderita remaja adalah skoliosis.

Skoliosis adalah kelainan tulang belakang yang bengkok ke kanan atau ke kiri dengan derajat kemiringan lebih dari 10 derajat (Aisyah dan Ambarwati, 2014). Sekitar $15-20 \%$ dari kasus skoliosis penyebab awalnya tidak diketahui, serta $80 \%$ kasus skoliosis struktural mempunyai etiologi idiopatik dan biasanya ditemukan pada anak-anak atau remaja (Rossi \& Alexander, 2004) Sebanyak 80-85\% kasus skoliosis ditemukan pada masa pubertas dan banyak di derita oleh perempuan daripada lakilaki (Adillani, 2015).

Gambaran klinis dari skoliosis, antara lain kelainan penampakan normal vertebra yaitu konkaf-konveks-konkaf yang terlihat menurun dari bahu ke bokong, menonjolnya iga di sisi konveks, tinggi krista iliaka yang tidak sama yang dapat menyebabkan satu tungkai lebih pendek daripada tungkai lainnya, asimetri rongga thoraks dan persambungan yang tidak sesuai dari vertebra spinalis akan tampak apabila individu membungkuk (Corwin, 2001).

Saat posisi membungkuk ke depan akan tampak deformitas dari prosessus spinosus, scapula yang menonjol, dan garis vertebral yang melengkung akibat abnormal pada kurva. Sedangkan bila pada posisi berdiri akan tampak tinggi bahu dan krista iliaka yang asimetris. Pada postur skoliosis, terjadi imbalance pada otototot paraspinal.

Indikasi observasi ialah skoliosis dengan sudut kurvatura $<25$ pada pasien yang masih dalam masa pertumbuhan dan $<50$ pada pasien yang masa pertumbuhannya telah berhenti. Pemeriksaan dilakukan setiap 6-9 bulan untuk kurvatura $<20$ dan tiap 4-6 bulan untuk kurvatura $>20$. Peralatan eksternal yang dapat digunakan untuk terapi skoliosis, antara lain gips plaster, brace, atau kombinasi. Tujuan penggunaan alat-alat ini ialah untuk mengoreksi kurvatura skoliosis yang ada atau mempertahankan koreksi yang telah dilakukan oleh terapi operasi. Penggunaan brace direkomendasikan pada skoliosis dengan kurvatura $>20$ pada pasien yang masih dalam masa pertumbuhan dan dengan progresifitas sebesar 5-10 dalam periode 6 bulan (Palealu, et al., 2014). 
Scoliosis brace adalah treatment yang biasa digunakan sebagai tindakan non operative untuk mencegah bertambahnya kurva skolosis. Banyak desain berbeda dari brace scoliosis, tetapi semua kembali pada objektivitas pasien sendiri. Tujuannya adalah untuk mengembalikan pada kontur normal dan menyelaraskan tulang belakang dengan cara kekuatan eksternal dan, dalam beberapa desain, stimulasi koreksi aktif tulang belakang pasien bergerak menjauh dari penekanan yang diberikan oleh brace (Weinstein, et al., 2013).

Mengutip pada Permenkes RI no.22 tahun 2013, Ortotik Prostetik adalah sebuah pelayanan kesehatan yang diberikan oleh Ortotis Prostetis dalam hal alat bantu kesehatan berupa orthosis maupun prosthesis untuk kesehatan fisik psikis berdasarkan ilmu pengetahuan dan teknologi untuk meningkatkan derajat kesehatan individu, kelompok dan masyarakat yang diakibatkan oleh adanya gangguan fungsi dan gerak anggota tubuh dan trunk (batang tubuh) serta hilangnya bagian anggota gerak tubuh yang dapat mengakibatkan kelainan/ gangguan anatomis, fisiologis, psikologis dan sosiologis.

Berdasarkan uraian diatas peneliti melakukan proses observasi sebagai studi pendahuluan untuk mengumpulkan informasi sebagai landasan dalam penelitian. Menurut observasi dan kejadian diatas, peneliti tertarik untuk melakukan penelitian mengenai gambaran kepercayaan diri pasien skoliosis dengan pegunaan skoliosis brace. Untuk itu peneliti ingin melakukan observasi dan wawancara kepada responden untuk mengetahui kepercayaan diri pasien saat pemakkaian skliosis brace dalam kehidupan sehari-hari. Penelitian ini terfokus pada gambaran kepercayaan diri pasien dengan menggunakan skoliosis.

\section{Metode Penelitian}

Penelitian ini menggunakan penelitian kualitatif. Penelitian kualitatif menghasilkan dan mengolah data yang bersifat deskriptif. Dalam penelitian ini, penulis ingin memberikan deskripsi mengenai gambaran kepercayaan diri pada pasien skoliosis yang menggunakan skliosis brace, dan tidak ada hipotesis yang diuji meskipun menggunakan teori yang ada.

Metode penelitian yang digunakan dalam penelitian ini adalah penelitian ini dilakukan dengan studi kasus yang bersifat intrinsik, yaitu kasus yang diambil merupakan kasus yang menarik untuk diteliti. Tujuan dari studi kasus adalah untuk memberikan gambaran secara mendetail tentang latar belakang, sifat- sifat serta karakter yang khas dari kasus, ataupun status dari individu, yang kemudian dari sifatsifat khas tersebut akan dijadikan suatu hal yang bersifat umum.

Sedangkan menurut Moleong (2000) pendekatan kualitatif adalah pendekatan yang bermaksud untuk memahami fenomena tentang apa yang dialami oleh subjek penelitian misalnya perilaku persepsi, motivasi, tindakan dan lain- lain. Secara holistik, dan dengan cara deskripsi dalam bentuk kata-kata dan bahasa, pada suatu konteks khusus yang alamiah dan dengan memanfaatkan berbagai metode alamiah.

Pendekatan penelitian adalah murni kualitatif dengan menggunakan metodemetode kontak langsung, yakni wawancara. Peneliti akan melakukan penelitian kualitatif dengan metode pengumpulan data secara wawancara terfokus (Poerwandari.2001). Gambaran kepercayaan diri penderita skliosis menggunakn skliosis brace ini akan diteliti dari data konkrit. Dimana subjek penelitian ini pasien skoliosis dengan cara wawancara terfokus langsung pada pasien yang bersangkutan. 
Sedangkan menurut Moleong (2000) pendekatan kualitatif adalah pendekatan yang bermaksud untuk memahami fenomena tentang apa yang dialami oleh subjek penelitian misalnya perilaku persepsi, motivasi, tindakan dan lain- lain. Secara holistik, dan dengan cara deskripsi dalam bentuk kata-kata dan bahasa, pada suatu konteks khusus yang alamiah dan dengan memanfaatkan berbagai metode alamiah.

Pendekatan penelitian adalah murni kualitatif dengan menggunakan metodemetode kontak langsung, yakni wawancara. Peneliti akan melakukan penelitian kualitatif dengan metode pengumpulan data secara wawancara terfokus (Poerwandari.2001). Gambaran kepercayaan diri penderita skoliosis menggunakan skoliosis brace ini akan diteliti dari data konkrit. Dimana subjek penelitian ini pasien skoliosis dengan cara wawancara terfokus langsung pada pasien yang bersangkutan.

\section{Tahap- Tahap Penelitian}

Tahap persiapan dan pelaksanaan yang akan dilakukan dalam penelitian ini meliputi beberapa tahapan yaitu :

\section{Tahap Persiapan Penelitian}

Langkah awal yang dilakukan oleh peneliti adalah membuat pedoman wawancara yang disusun berdasarkan teori-teori yang relevan dengan masalah penelitian ini. Pedoman wawancara ini berisi pertanyaan-pertanyaan mendasar yang nantinya dapat berkembang dalam wawancara. Pedoman wawancara yang telah disusun, sebelum digunakan dalam wawancara dikonsultasikan terlebih dahulu dengan yang lebih ahli atau significant other yang dalam hal ini adalah dosen pembimbing, peneliti melihat perbaikan terhadap pedoman wawancara dan mempersiapkan diri untuk melakukan wawancara.

Karena peneliti telah mendapatkan subjek, selanjutnya peneliti membuat kesepakatan dengan subjek dan mengatur waktu serta tempat pertemuan selanjutnya untuk melakukan wawancara berdasarkan pedoman yang telah dibuat.Peneliti juga perlu mempersiapkan tape recorder yang akan digunakan untuk merekam jalannya wawancara agar semua informasi akurat tidak ada yang terlupakan.

\section{Tahap Pelaksanaan Penelitian}

Sebelum melaksanakan proses wawancara peneliti perlu mengkonfirmasikan ulang pada para calon subjek penelitian untuk memastikan kesediaan mereka dan membuat kesepakatan mengenai waktu dan tempat pelaksanaan wawancara.

Dalam melaksanakan wawancara hal penting yang harus dilakukan sebelum memulai wawancara tersebut adalah dengan membangun rapport yang baik. Rapport sangat penting untuk membuat subjek merasa nyaman dan bebas dalam menjawab pertanyaan-pertanyaan yang diberikan, sehingga informasi yang diberikan akan lengkap dan akurat. Rapport juga merupakan usaha untuk ice breaking atau memecahkan kebekuan atau kekakuan yang ada selama proses wawancara berlangsung.

Dalam melakukan wawancara, peneliti berpatokan pada pedoman wawancara yang telah dibuat, serta merekam hasil wawancara tersebut pada tape recorder yang telah disediakan. Peneliti juga melakukan observasi selama wawancara dengan memperhatikan dan mencatat tingkah laku subjek selama wawancara, interaksi subjek dengan peneliti dan hal-hal lain yang dianggap relevan sehingga dapat memberikan data tambahan terhadap hasil wawancara. 


\section{Tipe Penelitian}

Penelitian ini menggunakan tipe studi kasus. Tipe studi kasus adalah fenomena khusus yang hadir dalam suatu konteks yang terbatasi (bounded context), meski batas-batas antara fenomena dan konteks tidak sepenuhnya jelas. Kasus itu dapat berupa kasus individu, peran, organisasi, kelompok kecil, komunitas atau bahkan suatu bangsa. Studi kasus deskriptif lebih memperhatikan deskripsi secara detail dari fenomena dalam konteksnya. Dalam penelitian studi kasus, fenomena khusus yang hadir adalah penggunaan skoiosis brace dalam merubah kepercyaan diri pasien. Tipe studi kasus yang digunakan dalam penelitian ini adalah studi kasus intrinsik. Penelitian dilakukan karena ketertarikan atau kepedulian pada suatu kasus khusus. Penelitian dilakukan untuk memahami secara utuh kasus tersebut tanpa harus dimaksudkan untuk menghasilkan konsep-konsep atau teori dan tanpa ada upaya untuk menggeneralisasi (Poerwandari, 2009). Pada studi kasus intrinsik, peneliti mempunyai ketertarikan atau kepedulian pada kasus ini (Wilig, 2001), yaitu perubahan beberapa aspek pada pasien skoliosis yang menggunakan skliosisbrace dalam hal kepercayaan diri, tanpa menghasilkan konsep-konsep atau teori, ataupun tanpa upaya menggeneralisasi.

\section{Metode Pengumpulan Data}

Teknik pengumpulan data yang akan digunakan dalam penelitian ini adalah wawancara danobservasi.

\section{Wawancara}

Menurut Poerwandari (2001) Wawancara adalah proses memperoleh keterangan untuk tujuan penelitian dengan cara tanya jawab sambil bertatap muka antara pewawancara dengan responden dengan mengunakan alat untuk mencapai tujuan tertentu yang mana adalah percakapan dan tanya jawab yang diarahkan untuk mencapai tujuan tertentu.

Pedoman wawancara ditulis secara rinci, lengkap dengan set pertanyaan dan penjabarannya dalam kalimat. Peneliti diharapkan dapat melaksanakan wawancara sesuai konsekuensi yang tercantum.

\section{Observasi}

Menurut Patton (dalam Poerwandari, 2001) salah satu hal yang penting tetapi sering dilupakan dalam observasi adalah mengamati hal yang tidak terjadi. Pada penelitian ini, peneliti melakukan observasi ditempat tinggal pasien. Peneliti melakukan observasi pada pasien saat menjalankan aktivitas sehari-hari menggunakan skliosis brace. Observasi dilakukan untuk mengamati segala aktivitas pasien skoliosis di lingkungan tempat tinggalnya.

Peneliti akan melakukan wawancara dengan pedoman wawancara yang terbuka. Pedoman wawancara ditulis secara umum, dengan pertanyaan dan penjabarannya yang bersifat fleksibel dalam kalimat. Peneliti akan melakukan wawancara kepada keluarga yang secara terus menerus berhadapan langsung dengan pasien,sehingga diharapkan dapat mengetahui secara rinci bagaimana gambaran kepercayaan diri pasien skoliosis saat menggunakan skliosis brace. Pertanyaan wawancara terdiri atas pertanyaan tentang kondisi kepercayaan diri sebelum menggunakan skoliosis brace dan setelah penggunan skoliosis brace.

Hasil observasi menjadi data yang penting karena :

a. Peneliti akan mendapatkan pemahaman yang lebih baik tentang konteks yang akan diteliti. 
b. Observasi memungkinkan peneliti untuk bersikap terbuka, berorientasi pada penemuan dari pada pembuktian dan mempertahankan pilihan untuk mendekati masalah secara induktif. Dengan berada dalam situasi lapangan yang nyata, kecenderungan untuk dipengaruhi berbagai konseptualisasi tentang topik yang diamati akan berkurang.

c. Mengingat individu yang telah sepenuhnya terlibat dalam konteks hidupnya sering mengalami kesulitan merefleksikan pemikiran mereka tentang pengalamannya, observasi memungkinkan peneliti melihat hal-hal yang oleh subjek penelitian sendiri kurang disadari.

d. Observasi memungkinkan peneliti memperoleh data tentang hal-hal yang karena berbagai sebab tidak diungkapkan oleh subjek penelitian secara terbuka dalam wawancara.

e. Jawaban terhadap pertanyaan akan diwarnai oleh perspektif selektif individu yang diwawancara. Berbeda dengan wawancara, observasi memungkinkan peneliti bergerak lebih jauh dari persepsi selektif yang ditampilkan subjek penelitian atau pihak-pihakl ain.

f. Observasi memungkinkan peneliti merefleksikan dan bersikap introspektif terhadap penelitian yang dilakukannya. Impresi dan perasaan pengamat akan menjadi bagian dari data yang pada gilirannya dapat dimanfaatkannya untuk memahami fenomena yang diteliti.

\section{Subjek Penelitian}

Subjek penelitian ini adalah satu pasien dengan deformitas skoliosis yang sudah menggunakan skoliosis brace dengan sudut lengkungan 60 derajat. Alasan memilih subjek karena dari data menunjukkan bahwa populasi skliosis terbesar ada pada remaja perempuan. Umur dari subjek dalam penelitian ini adalah 14 tahun. Sedangkan kelas ekonomi pasien dan keluarga pasien ditentukan pada golongan ekonomi menengah keatas. Pekerjaan pasien sebagai siswa di sekolah menengah pertama.

\section{Keabsahan dan Keakuratan Penelitian}

Yin (1994) mengajukan empat kriteria keabsahan dan keakuratan yang diperlukan dalam suatu penelitian kualitatif, yaitu:

1. Keabsahan Konstruk (Construct Validity)

Keabsahan konstruk berkaitan dengan kepastian bahwa yang terukur benarbenar merupakan variabel yang ingin diukur. Keabsahan ini dapat dicapai dengan proses pengumpulan data yang tepat. Salah satu caranya adalah dengan proses triangulasi, yaitu teknik pemeriksaan keabsahan data yang memanfaatkan sesuatu yang lain di luar data itu untuk keperluan pengecekan atau sebagai pembanding terhadap data itu. (Patton, 2002)

\section{Keabsahan Internal (Internal Validity)}

Keabsahan internal merupakan konsep yang mengacu pada seberapa jauh kesimpulan hasil penelitian menggambarkan keadaan sesungguhnya. Keabsahan ini dapat dicapai melalui proses analisis dan interpretasi yang tepat. Aktivitas dalam melakukan penelitian kualitatif akan berubah dan tentunya akan mempengaruhi hasil dari penelitian tersebut. Sehingga walaupun telah dilakukan uji keabsahan internal, tetap ada kemungkinan munculnya kesimpulan yang lain yang berbeda.

\section{Keabsahan Eksternal (Exsternal Validity)}


Keabsahan yang mengacu pada seberapa jauh hasil penelitian dapat di generalisaikan pada kasus lain. Walaupun dalam penelitian kualitatif memiliki sifat tidak ada kesimpulan akhir yang pasti, penelitian kualitatif tetap dapat dikatakan memiliki keabsahan eksternal terhadap kasus-kasus lain selama kasus tersebut memiliki konteks yang sama.

\section{Keajegan (Reliability)}

Keajegan merupakan konsep yang mengacu pada seberapa jauh penelitian berikutnya akan mencapai hasil yang sama apabila mengulang penelitian yang sama sekali lagi. Dalam penelitian kualitatif, keajegan mengacu pada kemungkinan peneliti selanjutnya memperoleh hasil yang sama apabila penelitian dilakukan sekali lagi dengan subjek yang sama. Hal ini menunjukkan bahwa konsep keajegan penelitian kualitatif selain menekankan pada desain penelitian, juga pada cara pengumpulan data dan pengolahan data.

Untuk meningkatkan keajegan diperlukan protokol penelitian yang jelas, seperti pedoman wawancara yang akan membuat pertanyaan yang diajukan akan lebih terarah. Hal penting lainnya adalah pertanyaan yang diajukan pada tiap subjek harus sama, dengan tujuan bila peneliti ini diulang hasil yang keluar akan sama. Walaupun dalam penelitian ini menggunakan wawancara tak terstruktur ini untuk mendapatkan gambaran yang lebih mendalam tentang subjek terlepas dari subjektivitas penelitian.

\section{Hasil dan Pembahasan Analisa Subjek}

Proses pelayanan Ortotik Prostetik menurut PMK RI Nomor 27 Tahun 2015 merupakan tata cara atau tahapan yang dilakukan dan yang harus dilalui untuk menyelesaikan suatu proses kerja tertentu. Proses pelayanan Ortotik Prostetik dalam Skoliosis Bracemeliputi :

1. Pemeriksaan/Assesment

Suatu rangkaian kegiatan penegakan diagnosa Ortotik Prostetik yang meliputi:

a. Anamnesis

Suatu proses wawancara terhadap pasien/klien dan keluarganya untuk memperoleh informasi yang dibutuhkan untuk mendukung kebutuhan alat bantu yang akan dipasangkan. Anamnesis dilakukan terhadap keluarga, ortosis prostetis dan informasi dari dokter yang menangani pasien tersebut.

b. Observasi

Suatu kegiatan pemeriksaan secara singkat keadaan umum dan keadaan lain pasien/klien.

c. Adam Forward bending Test

Adam Forward Bending Test merupakan skrining pada skoliosis, dengan cara pasien diminta untuk berdiri kemudian membungkuk ke arah depan. Pemeriksaan lainnya menggunakan plumb line, yaitu alat berupa bandul panjang, yang melewati kepala, badan, dan midline dari gluteal, yang berperan sebagai garis yang mewakili garis vertikal tubuh terhadap gaya gravitasi dalam bidang sagital. Pengukuran derajat lengkung kurva pada skoliosis selain dengan X-Ray juga bisa dilakukan dengan menggunakan alat ukur berupa inclinometer. Inclinometer merupakan suatu instrument yang mengukur trunk asimetri dalam skoliosis. Inclinometer adalah perangkat non-invasif kecil yang ditempatkan di atas tulang belakang sementara orang yang diukur berada dalam posisi membungkuk ke depan.

Hasil dari pengukuran dengan skliosis dapat dilihat dari batang asimetri derajat yang tertera pada Cobb Angle. Metode inclinometer untuk mengukur axial trunk 
rotasi (ATR) dapat dilakukan dengan cepat, murah dan mudah dipelajari.

2. Penegakan diagnosa Ortotik Prostetik

Suatu bentuk kesimpulan pemeriksaan yang akan menjadi patokan rancang bangun pembuatan atau pemberian Orthosis/Prostesis.

3. Pengukuran

Suatu kegiatan pengambilan contoh/model dari pasien/klien, berupa ukuran atau negatif model sebagai pedoman utama dalam proses pembuatan Orthosis atau Prosthesis. Pengukuran dilakukan pada body pasien.

4. Fabrikasi

Rangkaian proses kegiatan pembuatan alat bantu Ortosis atau Prostesis. Pengepasan rangkaian kegiatan pemasangan awal Ortosis atau Prostesis untuk melihat kesesuaian dan kenyamanan alat pada pasien/klien. Proses pembuatan Orthosis ini terdiri dari thermforming menggunakan plastik yang dikombinasikan dengan besi penyangga bagian anterior dan posterior

5. Finishing

Rangkaian kegiatan penyempurnaan dalam rangka kesesuaian, kekuatan, kenyamanan, dan estetika Ortosis Prostesis. Pemasangan dan Penyerahan Proses aplikasi Ortosis atau Prostesis secara langsung dari Ortotis Prostetis kepada pasien/klien.

6. Informasi dan Edukasi

Penyampaian informasi dan edukasi kepada pasien/klien tentang penggunaan, perawatan, pantangan, dan perkembangan secara berkala dari pemakaian Ortosis atau Prostesis dilakukan secara lisan dan tertulis. Selain informasi dan edukasi, ortotis protetis juga harus memberikan motivasi kepada klien/pasien.

7. Evaluasi

Evaluasi dilakukan secara berkala untuk memantau secara bertahap hasil positif atau negatif dari penggunaan Ortosis maupun Prostesis untuk dilakukan tindak lanjut penanganannya. Proses pelayanan Ortotik Prostetik merupakan tata cara atau tahapan yang dibakukan dan yang harus dilalui untuk menyelesaikan suatu proses kerja tertentu.

\section{Gambaran umum subjek}

Dalam analisa ini terdapat gambaran umum subjek, hasil observasi pemakaian Skoliosis Brace dan hasil wawancara dengan keluarga (ibu) subjek tentang kondisi pasien sebelum dan sesudah menggunakan skoliosis brace.

\section{Gambaran umum subjek}

Pasien yang menjadi subjek penelitian ini bernama $\mathrm{KN}$. KN adalah seorang remaja putri berumur 14 tahun. KN lahir di Surabaya, 18 Januari 2005 . KN tinggal di Kenjeran, Surabaya. Saat ini KN sedang menempuh pendididkan Sekolah Menengah Pertama di sebuah sekolah di Surabaya. Jenis kelamin perempuan dengan tinggi dan berat badan 159/53.

KN termasuk anak yang cerdas dan aktif disekolahnya. la mengikuti ekstrakulikuler English club dan mathematic. KN juga mengikuti terapi renang secara teratur.

Sebelumnya pasien tidak pernah menyadari ada sesuatu yang berbeda pada punggungnya dan tidak pernah mengeluh adanya sakit di sekitar punggung maupun terasa sesak nafas. Hingga suatu ketika saat usia12 tahun ia mengalami sakit dan 
harus dibantu dengan ibunya untuk berganti pakaian. Ibu dari pasien melihat adanya tonjolan seperti punuk yang ada di sebelah kanan punggung pasien yang kemudian muncul kecurigaan terhadap perubahan bentuk tubuh pasien.

Si ibu pun berusaha mencari tahu apa yang sebenarnya terjadi pada sang anak, dan bertanya kepada beberapa rekan kerjanya jika terjadi keanehan pada punggung sang anak. Sang ibu menduga anak mengalami skliosis, seperti yang sudah pernah di pelajarinya saat di sekolah. Setelah mencari tahu apa yang terjadi, ada salah seorang teman yang mengatakan bahwa anak ibu mengalami skliosis dan menyarankan untuk dibawa ke dokter. Dokter memvonis pasien dengan penyakit skliosis dan diminta untuk foto rontgen sebagai tindak lanjut, kemudian diketahui derajat skliosis sudah mencapai 60 derajat dan dokter menyarankan agar menyetujui tindakan operasi.

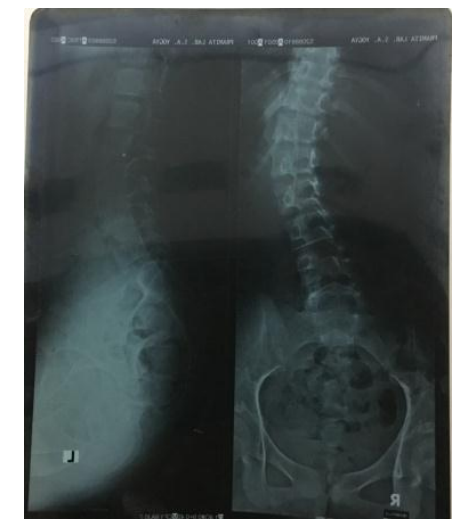

Gambar 1 (Foto rontgen pasien dengan sudut 60 derajat).

Oleh karena resiko besar yang harus dihadapi ketika memutuskan untuk operasi, maka dari pihak orang tua pun menolak dan mencari solusi lain untuk mengobati skoliosis sang anak. Dengan kondisi skoliosis yang cukup parah dan postur tubuh yang bengkok, pasien masih tetap menjalankan aktivitasnya seperti biasa bermain dengan teman-temannya, dengan tetap percaya diri bahwa postur tubuhnya tidak akan membahayakan bagi dirinya. Teman-teman sebayanya pun tidak pernah mempermasalahkan kondisi pasien yang seperti memiliki punuk di punggung.

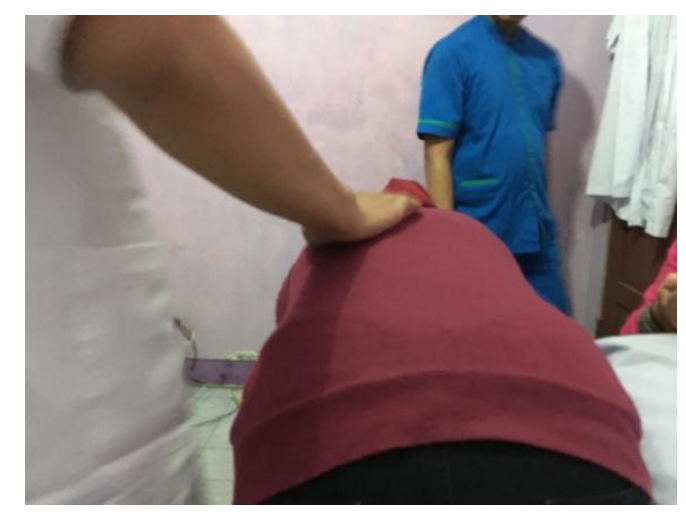

Gambar 2 (Pasien diminta melakukan Forward Bending Test dengan hasil terlihat adanya rib hump/tonjolan di sisi punggung sebelah kanan)

Adanya tonjolan pada punggung sebelah kanan dikarenakan adanya rotasi pada vertebra pasien. Rotasi ini akan mendorong scapula dan akan terlihat menonjol. Sama seperti yang dikemukakan oleh Kusumi\& Dunwoodie, 2010 bahwa lengkungan yang cembung ke kanan memperllihatkan berbagai derajat rotasi, 
menyebabkan penonjolan iga (rib hump). Jika pasien dilihat dari belakanag dapat memperlihatkan deviasi lateral processus spinosus dari garis tengah. Pada kurva thoracal, tampak punggung yang miring, rib hump, dan asimetri scapula. Pada kurva lumbal tampak penonjolan asimetris salah satu panggul.

Menurut Pelealu, et al., 2014 gejala-gejala yang paling umum dari skoliosis ialah suatu lekukan yang tidak normal dari tulang belakang, dan menyebabkan kepala nampak bergeser dari tengah. Masalah yang dapat timbul akibat skoliosis ialah penurunan kualitas hidup dan disabilitas, nyeri, deformitas yang mengganggu secara kosmetik, hambatan fungsional, masalah paru, kemungkinan terjadinya progresifitas saat dewasa, dan gangguan psikologis.Akan tetapi, pasien tidak pernah mengeluh adanya nyeri di pungung dan sesak nafas, sudut skoliosis cukup besar padahal semakin besar sudut akan meningkatkan resiko disfungsi paru dan corpilmonale yang dapat menyebabkan sesak nafas.

Kondisi yang lebih berbahaya lagi jika sudut kemiringannya besar dan terjadi di bagian dada (thoracic), tulang rusuk skoliosis dapat menekan paru-paru dan jantung, dimana paru-paru pada sisi yang terdorong tidak bisa berkembang maksimal karena rongga thorak menyempit termakan oleh tulang yang bengkok. Akibatnya pernapasan terganggu, dada menjadi sesak dan penyandang skoliosis akan kesulitan bernafas dan cepat lelah. Jantung juga akan mengalami kesulitan dalam memompa darah.

Pada pilihan kedua, orang tua pasien menghendaki penggunaan brace skoliosis atas saran dari dokter lain, dengan alasan penggunaan brace tidak akan membahayakan sang anak daripada tindakan operasi. Setelah penggunaan alat skoliosis brace, pasien merasakan benar-benar ada tekanan pada tubuhnya, dan ini membuatnya tidak nyaman dan sulit untuk bergerak bebas. Akhirnya pasien tidak dapat mengikuti mata pelajaran olahraga yang terlalu berat, seperti lari, lompat jauh dan sebagainya. Meskipun pemakaian brace tidak cukup menonjol dalam merubah penampilannya, akan tetapi ini dapat membatasi ruang gerak pasien dan pasien merasa bergerak seperti robot.

Keadaan ini membuatnya merasa berbeda dari teman sebayanya dan perasaan percaya diri pasien mulai menurun. Hal ini sejalan dengan pendapat Santrock, 2003 yang menyatakan bahwa penampilan fisik merupakan factor yang mempengaruhi kepercayaan diri seseorang. Sejumlah peneliti telah menemukan penampilan fisik merupakan suatu kontributor yang sangat berpengaruh pada rasa percaya diri remaja.

\section{Analisis Hasil Observasi Subjek Penggunaan Skoliosis Brace}

Dari hasil obsevasi penggunaan skoliosis brace dapat dilihat bawasannya pasien memiliki rasa percaya diri yang menurun dikarenakan tekanan yang ada pada alat skoliosis brace dan bunyi yang dihasilkan oleh alat tersebut. Pasien merasa kurang nyaman dan malu karena tidak dapat lagi bergerak dengan bebas dengan dibatasi skoliosis brace tersebut. Terkadang pasien merasa down dan sangat berat untuk memulai harinya memakai skoliosis brace, akan tetapi support dari orang tua dan keluarga mudah membangkitkan semangatnya untuk sembuh dan sedikit meningkatkan rasa percaya dirinya. Disamping itu, teman-teman sekolah pasien tidak pernah mempermasalahkan keadaan dan pemakaian brace pasien, mereka malah mendukung agar pasien tetap menjalani terapi dengan alat skoliosis brace dan ini menumbuhkan rasa percaya diri pasien sekali lagi. 
Dari sinilah pasien mencoba untuk menerima keadaan berkat dukungan dari orang tua dan teman sebayanya. Dimana menurut Santrock, 2003 hubungan keduaanya merupakan factor yang mempengaruhi kepercayaan diri pasien.

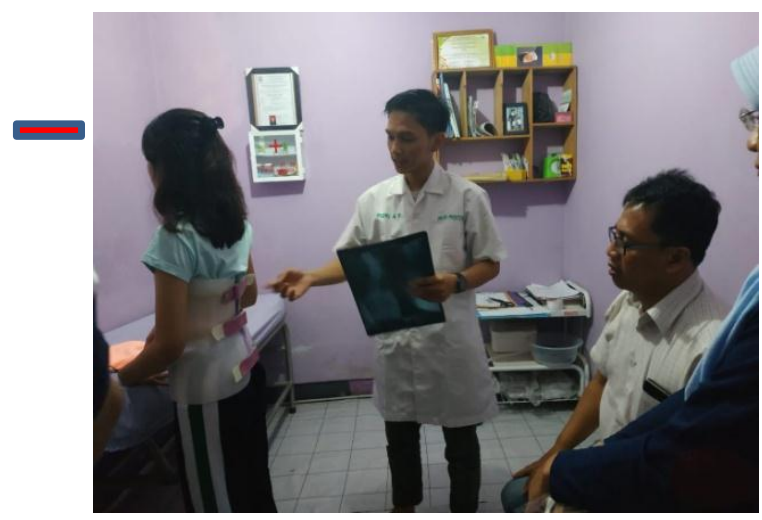

Gambar 3 (Pasien tetap beraktifitas seperti biasa dengan menggunakan skoliosis brace).

Meskipun pemakaian skoliosis brace berada di dalam baju, akan tetapi pasien masih merasa malu tatkala keluar rumah dan dalam kondisi memakainya, karena alasan tidak bisa bergerak dengan bebas dan pasien mengeluhkan munculnya bunyi pada skoliosis brace ini. Agar tidak terlihat saat memakai skliosis brace, pasien berusaha menutupinya dengan cara menggunakan baju yang sedikit longgar, sehingga besi yang berada di anterior dan posterior tidak terlihat jelas bentukknya.

Hal ini sejalan dengan Fatimah, 2010 mengenai ciri-ciri individu yang tidak memiliki rasa percaya diri yaitu sulit menerima realita diri (terlebih menerima kekurangan diri) dan memandang rendah kemampuan diri sendiri-namun di lain pihak, memasang harapan yang tidak realistik terhadap diri sendiri.

\section{Simpulan Subjek}

Berdasarkan hasil observasi, wawancara, dan analisa terhadap gambaran kepercayaan diri penderita skoliosis menggunakan skoliosis brace, kini pasien mempunyai tingkat kepercayaan diri yang kurang baik saat menggunakan dan saat tidak menggunakan alat skoliosis brace. Karena saat tidak menggunakan skoliosis brace punggung pasien akan terlihat seperti mempunyai punuk dan ketika menggunakan skoliosis brace, pasien merasa tubuhnya seperti robot yang tidak dapat bergerak dengan bebas dan alat skoliosis brace yang sering berbunyi yang berasal dari besi- besi di depan dan belakang. Maka dapat disimpulkan bahwa penggunan skoliosis brace dapat mengurangi tingkat kepecayaan diri pasien yang mengalami skoliosis.

\section{Kesimpulan dan Saran}

Pengunaan skoliosis brace dapat mengurangi rasa kepercayaan diri pada pasien skoliosis. Meskipun pemakaian brace yang tertutup oleh baju, hal ini masih menimbulkan rasa tidak nyaman dan malu kala memakainya. Bunyi yang ditimbulkan dan keterbatasan gerakan juga mempengaruhi rasa percaya diri pada pasien.

Penggunaan skoliosis brace seharusnya mengikuti saran dari ortotis prostetis, mengenai waktu pemakaian, agar treatment maksimal dan mencegah kecacatan yang lebih lanjut. Sebaiknya pasien tidak perlu menghawatirkan lingkungan agar hal ini tidak menurunkan rasa kepercayaan diri. Dan pasien harus tetap semangat menjalankan hari emi hari mengnakan scoliosis brace karena tujuannya adalah untuk memperbaiki postur tubuh agar lebih baik. 


\section{Daftar Pustaka}

Aisyah, K., \& Ambarwati, S. (2014). Dipetik 16 November, 2016, dari http://suaramahasiswa.com/faktor-kebiasaan-bukan-penyebab-skoliosis/

Deni, AU., Ifdil. (2016 ). Konsep kepercayaan Diri Remaja Putri.Universitas Negeri Padang. Journl Educatio.

Moleong, J.L, (2000) .Metodologi Penelitian Kualitatif (Edisi Revisi). Bandung: PT. Remaja Rosdakarya.

Kusumi, K. \& Dunwoodie, S. L. (2010). The Genetics and Development of Scoliosis . New York : Springer.

Palelau, J., Angliadi, L. S., \&Angliadi, E. (2014). Rehabilitasi medic pada Soliosis. Jurnal Biomedik, 6 (1), 8-13.

Pemenkes RI. (2013). Pengertian Ortotik Prostetik : 22 Peraturan Menteri Kesehatan Republik Indonesia Nomor 27 Tahun 2015 Tentang Standar Pelayanan Ortotik Prostetik

Poerwandari, K. (2001) .Pendekatan Kualitatif Untuk Penelitian Perilaku Manusia. Jakarta : Lembaga Pengembangan Sarana Pengukuran \& Pendidikan Psikologi (L P S P 3) Universitas Indonesia.

Rogala EJ, Drummond DS, Gurr J. Skliosis: Incidence and natural history. Aprospective epidemiological study. J Bone Joint Surg Am 1978;60:173-6.

Rossi R, Alexander M. Pediatric Rehabilitation. In: Cucurullo SJ, editor. Physical Medicine and Rehabilitation Board Review. New York: Demos Medical Publishing, 2004; p.665-7.

Santrock, Jhon, W. (2003). Adolescene: Perkembangan Remaja. Terjemahan oleh Shinto B. Adelar dan Sherly Siragih. Jakarta: Erlangga.

Weinstein S.L., Dolan Lori., Wright James., Dobbs Matthew. 2013. Effect of bracing in adolescents with idiopathic skoliosis. NewEngland, Journal of Medicine. 